\title{
Trophic niche differentiation and microhabitat utilization revealed by stable isotope analyses in a dry-forest bat assemblage at Ankarana, northern Madagascar
}

Suggested citation referring to the original publication:

Journal of Tropical Ecology 30 (2014) 2, pp.97-109

DOI https://doi.org/10.1017/S0266467413000825

ISSN (print) 0266-4674

ISSN (online) 1469-7831

Postprint archived at the Institutional Repository of the Potsdam University in:

Postprints der Universität Potsdam

Mathematisch-Naturwissenschaftliche Reihe ; 595

ISSN 1866-8372

https://nbn-resolving.org/urn:nbn:de:kobv:517-opus4-415157

DOI https://doi.org/10.25932/publishup-41515 



\title{
Trophic niche differentiation and microhabitat utilization revealed by stable isotope analyses in a dry-forest bat assemblage at Ankarana, northern Madagascar
}

\author{
Melanie Dammhahn*,1 and Steven M. Goodman $\dagger \ddagger$ \\ * Behavioral Ecology \& Sociobiology Unit, German Primate Center (DPZ), Leibniz Institute for Primate Research, Kellnerweg 4, D-37077 Göttingen, Germany \\ $\dagger$ Association Vahatra, BP 3972, Antananarivo 101, Madagascar \\ ‡ Field Museum of Natural History, Science and Education, 1400 South Lake Shore Drive, Chicago, Illinois 60605, USA \\ (Received 1 September 2013; revised 18 November 2013; accepted 18 November 2013; first published online 16 December 2013)
}

\begin{abstract}
Bats are important components in tropical mammal assemblages. Unravelling the mechanisms allowing multiple syntopic bat species to coexist can provide insights into community ecology. However, dietary information on component species of these assemblages is often difficult to obtain. Here we measured stable carbon and nitrogen isotopes in hair samples clipped from the backs of 94 specimens to indirectly examine whether trophic niche differentiation and microhabitat segregation explain the coexistence of 16 bat species at Ankarana, northern Madagascar. The assemblage ranged over $4.4 \%$ in $\delta^{15} \mathrm{~N}$ and was structured into two trophic levels with phytophagous Pteropodidae as primary consumers (c. 3\% enriched over plants) and different insectivorous bats as secondary consumers (c. 4\%o enriched over primary consumers). Bat species utilizing different microhabitats formed distinct isotopic clusters (metric analyses of $\delta^{13} \mathrm{C}-\delta^{15} \mathrm{~N}$ bi-plots), but taxa foraging in the same microhabitat did not show more pronounced trophic differentiation than those occupying different microhabitats. As revealed by multivariate analyses, no discernible feeding competition was found in the local assemblage amongst congeneric species as compared with non-congeners. In contrast to ecological niche theory, but in accordance with studies on New and Old World bat assemblages, competitive interactions appear to be relaxed at Ankarana and not a prevailing structuring force.
\end{abstract}

Key Words: Ankarana, canopy effect, Chiroptera, coexistence, community structure, congeneric species, dry deciduous forest, Madagascar

\section{INTRODUCTION}

Understanding the mechanism allowing species to coexist in local communities remains one of the major topics in community ecology. Niche theory states that there are limits in similarity of co-occurring species (reviewed in Chase \& Leibold 2003). The order Chiroptera is well suited to test this fundamental hypothesis, because bats often represent the most species-rich and ecologically diverse group, particularly in the tropics, of locally occurring mammals (Kingston 2009, Rex et al. 2008). However, due to their often relatively small size and nocturnal lifestyle, ecological information on the local assemblage is difficult to obtain. As a result, the mechanisms facilitating the local coexistence of bat species are generally poorly understood,

\footnotetext{
${ }^{1}$ Corresponding author: Email: mdammha@gwdg.de
}

which is particularly true for the Old World, including Madagascar.

Research on chiropteran community composition and structure has mainly focused on microhabitat and trophic resource partitioning and revealed that bat assemblages can comprise a variety of different trophic groups with further specializations in foraging strategies, functional morphology, sensory ecology and dietary composition within trophic groups or among congeneric species (Aguirre et al. 2002, 2003; Norberg 1994, Siemers \& Schnitzler 2004). Furthermore, bat species show specific adaptations in echolocation (Schnitzler et al. 2003) and wing morphology (Norberg 1994) to forage in threedimensional habitat space and segregate by spatial partitioning.

Recently, considerable advances have been made concerning aspects of the taxonomy and distribution of Malagasy bats, which increased the number of recognized 
species from 27 (Peterson et al. 1995) to 45, of which $77 \%$ are endemic to the island (Goodman 2011, Goodman et al. 2011, 2012a). Hitherto, ecological differentiation in assemblages of Malagasy bat species remain unresolved. Here, we focus on one of the more species-rich and intensively surveyed assemblages on the island, from the Ankarana limestone area in the north (Cardiff 2006, Goodman et al. 2005, 2006, 2012b). We aim to indirectly study microhabitat use and diet composition of bat species and thereby illuminate the mechanisms that facilitate their coexistence in this assemblage.

Traditionally, faecal analyses of pellets, as well as analyses of stomach contents, have been used to identify and quantify the proportion of different dietary components of bats (Voigt et al. 2009, Whitaker et al. 2009). These methods have drawbacks in that they only provide a snapshot in time on the feeding behaviour. Recently, the use of stable isotopes has been employed to provide detailed insights into the feeding ecology of bat species (Fleming et al. 1993, Herrera et al. 2001, 2002; Voigt \& Kelm 2006, Voigt et al. 2008) and to assess trophic relationships in communities (Rex et al. 2010, 2011; Voigt 2010).

Here, we use stable nitrogen and carbon isotope signatures in hair from individuals of 16 sympatric bat species (Appendix 1) as integrated information about assimilated food over several weeks (DeNiro \& Epstein 1978, 1981; Eggers \& Jones 2000) and, thus, indirect indicators of trophic niches of these taxa. We focused on the following hypotheses and predictions: (1) The assemblage is structured into different trophic levels. Since the assemblage contains both largely frugivorous/nectarivorous and insectivorous taxa, we predict that the assemblage has more than one trophic level, i.e. a $\delta^{15} \mathrm{~N}$ range $\geq 3 \%$ (McCutchan et al. 2003, Vanderklift \& Ponsard 2003). (2) The assemblage is trophically structured into different ensembles. Based on field data, the assemblage includes species foraging in different microhabitats. Since $\delta^{13} \mathrm{C}$ increases with canopy height (Medina \& Minchin 1980), we predict increased $\delta^{13} \mathrm{C}$ in species foraging higher in the canopy and in open areas as compared to species foraging in lower portions of the canopy. Furthermore, we expect the centroids (i.e. arithmetic mean of $\delta^{13} \mathrm{C}$ and $\delta^{15} \mathrm{~N}$ ) to differ between ensembles. (3) Bat species are separated into trophic niches. We predict species to occupy different trophic niches, indicated by species-specific isotopic signatures. In particular, we expect species sharing the same microhabitat to show greater differentiation into trophic niches than those of different microhabitats, indicated by larger nearest-neighbour distances. (4) Coexisting congeneric species are trophically more similar as compared with non-congeneric species. Because of phylogenetic inertia and similarity in morphology, we expect interspecific competition among sympatric congeners to be larger than among non-congeners, indicated by low nearest-neighbour distances between these species.

\section{METHODS}

\section{Study site}

The Ankarana is a large limestone massif deeply sculpted by the action of water, forming a karstic landscape with many caves and crevices, ideal day-roosting sites for numerous species of bats (Cardiff 2006). Four distinct habitats occur in the Ankarana: (1) dry deciduous forests, (2) dry forest on limestone, (3) barren areas of rock, and (4) peripheral anthropogenic grassy woodlands. The zone receives approximately $1900 \mathrm{~mm}$ of annual rainfall, mostly falling between December and April, resulting in a 7-mo dry season (Cardiff \& Befourouack 2003). During the dry period, virtually no standing water occurs on the ground surface.

\section{Sampling and specimens}

The second author has conducted projects with several colleagues on the bat fauna of Ankarana. Most collected specimens were preserved in $12 \%$ formaldehyde for approximately $1 \mathrm{mo}$, washed in flowing water for at least $24 \mathrm{~h}$, transferred to $65-75 \% \mathrm{ETOH}$, and stored in glass jars out of direct sunlight. Subsequently, hair samples were clipped from the lower back of catalogued specimens, placed in individual vials, and then air-dried in open vials.

We collected hair samples from specimens of 16 species of six bat families, 12 endemic to Madagascar and three endemic to the Malagasy Region (Madagascar and the Comoros Archipelago) (Appendix 1). These included all of the known bats to occur in the Ankarana, excluding Pteropus rufus (Pteropodidae), the largest frugivore on Madagascar. We obtained six hair samples per species, with the exceptions of Eidolon dupreanum and Chaerephon leucogaster, for which only five samples each were available. The animals representing a given taxon were not necessarily using the same day-roost site. All specimens were from the Ankarana with the exceptions of Mops leucostigma samples collected at the park periphery or a synanthropic roost site at the edge of a nearby village (Ambilobe) and those of C. leucogaster collected from the same synanthropic roost. The M. leucostigma material from the park boundary and the village did not differ in $\delta^{15} \mathrm{~N}$, but those collected in the village were lower in $\delta^{13} \mathrm{C}$ (c. $2 \%$ ). The C. leucogaster samples from near Ambilobe were similar in $\delta^{13} \mathrm{C}$ and $\delta^{15} \mathrm{~N}$ to other Molossidae.

There is a very marked dry season at Ankarana, between May and November, presumably causing 
notable seasonal differences in density and diversity of food resources available to bats, particularly insectivorous species, as known from other sites on Madagascar (Ramasindrazana et al. 2012). In an attempt to control for seasonality, we have chosen individuals collected during the dry season. In a few cases, this was not possible and for E. dupreanum and Rousettus madagascariensis there is one individual per species from January and for Hipposideros commersoni two individuals from January. No information is available on when Ankarana bat species replace their hair, or in other words, the moment they assimilate the stable isotopes represented in the hair samples. Our assumption is that these different species are not migratory. In addition, samples of leaves of common forest trees ( $\mathrm{C} 3$ plants) and of arthropods were collected in areas of the Ankarana where bat samples were obtained to establish baseline habitat data for stable isotopes.

\section{Stable isotope analysis}

Prior to analyses, all samples were oven-dried at $60^{\circ} \mathrm{C}$ until weight was constant to remove tissue water. Leaf samples were ground and homogenized with a ball mill. For determination of carbon and nitrogen isotope ratios, $1 \mathrm{mg}$ of either homogenized leaves, parts of arthropods (abdomen, legs) or whole specimens of small arthropods, or whole hairs of bat specimens were enclosed into tin capsules. Mass spectrometry analyses were carried out at the Centre for Stable Isotope Research \& Analysis (KOSI) in Göttingen (Germany), using an isotope ratio mass spectrometer (Delta Plus, Finnigan MAT, Bremen, Germany) in an online system after passage through an element analyser (NA 1110, Carlo Erba, Milan, Italy). Since the ratio between the heavy and the light isotopes is small and subject to natural fluctuations, the isotope data are compared with a standard and presented in $\delta$ notation calculated as follows:

$$
\delta \mathrm{X}=\left[\left(\mathrm{R}_{\text {sample }} / \mathrm{R}_{\text {standard }}\right)-1\right] \times 10^{3}
$$

Where $\delta \mathrm{X}$ is $\delta^{15} \mathrm{~N}$ or $\delta^{13} \mathrm{C}$, and $\mathrm{R}$ is the respective ${ }^{15} \mathrm{~N} /{ }^{14} \mathrm{~N}$ or ${ }^{13} \mathrm{C} /{ }^{12} \mathrm{C}$ ratio. The international standards are atmospheric air for nitrogen and PDB (Pee Dee Belemnite marine carbonate) for carbon. Analytical error was calculated based on the within-run standard deviations of the working standard, acetanilide, and ranged 0.08$0.10 \%$ for $\delta^{15} \mathrm{~N}$ and $0.06-0.10 \%$ for $\delta^{13} \mathrm{C}$.

\section{Data analyses}

First, we analysed $\delta^{13} \mathrm{C}-\delta^{15} \mathrm{~N}$ bi-plots based on mean values of species to characterize the community as a whole (Layman et al. 2007). We calculated four different measures of community trophic diversity: (1) total $\delta^{15} \mathrm{~N}$ range signifying the number of trophic levels; (2) total $\delta^{13} \mathrm{C}$ range indicating variation in basal resources; (3) the total area covered by the community calculated as a minimum convex polygon with ArcView3.3 (Animal movement extension, ESRI) and the standard ellipse (Jackson et al. 2011) indicating the isotope niche space covered by the community; and (4) the mean distance of each species to the community centroid (mean $\delta^{15} \mathrm{~N}$ and mean $\delta^{13} \mathrm{C}$ over all species) representing average trophic diversity in the community. Further, we calculated two measures to estimate trophic and niche packing parameters: (1) the mean Euclidean distance to nearest neighbours indicating niche packing; and (2) the standard deviations of distances to nearest neighbours reflecting the evenness of species distribution in isotopic niche space. Finally, we assessed whether the packing of species in the community $\delta^{13} \mathrm{C}-\delta^{15} \mathrm{~N}$ bi-plot deviates from a random pattern using the Clark \& Evans (1954) nearest-neighbour analysis for spatial distribution (Krebs 1998). We calculated an index of aggregation (R), based on observed nearest-neighbour distances $\left(\mathrm{NND}_{\mathrm{obs}}\right)$ in relation to expected nearest neighbour distances of species in the $\delta^{13} \mathrm{C}-\delta^{15} \mathrm{~N}$ bi-plot area covered by the whole community. The index of aggregation calculation is: $\mathrm{R}=\mathrm{NND}_{\text {obs }} / \mathrm{NND}_{\text {exp }}$, with $\mathrm{NND}_{\text {obs }}=\Sigma \mathrm{NND}_{\mathrm{i}} / \mathrm{N}$ and $\mathrm{NND}_{\text {exp }}=1 /(2 \sqrt{ } \mathrm{P})$. The density $(\mathrm{P})$ is given by $\mathrm{P}=\mathrm{N} /$ area with $\mathrm{N}=$ number of species and area $=$ total area covered by the community calculated as a convex hull area. If $\mathrm{R}=1$, the spatial pattern is random; if $\mathrm{R}$ approaches 0 , the spatial pattern is clumped; and if $\mathrm{R}$ approaches 2.15 , the spatial pattern is regular (Krebs 1998).

Second, we used a general hypothesis-testing framework for stable isotope data proposed by Turner et al. (2010) and compared differences in centroid location and dispersion metrics across three ensembles in the $\delta^{13} \mathrm{C}-\delta^{15} \mathrm{~N}$ bi-plot. Our sample contains two species of Pteropodidae, which feed predominantly on fruits. These bats use a variety of habitat types including the forest mid- to upper-canopy and isolated trees in open areas. Further, our sample contains insectivorous species, which use different microhabitats in and around the forest: (1) species foraging in the lower portion of the forest, up to about 5-7 m; and (2) species that forage above the canopy and in open areas. Based on these differences in feeding ecology and microhabitat use, we classified bats into the following ensembles: (1) frugivore mid-upper canopy ( $\mathrm{n}=2$ species); (2) insectivore open space $(\mathrm{n}=6$ species); and (3) insectivore lower canopy ( $\mathrm{n}=8$ species) (Appendix 1).

To assess whether ensembles occupy different portions of the $\delta^{13} \mathrm{C}-\delta^{15} \mathrm{~N}$ bi-plot, we compared differences in Euclidean distances between ensemble centroids (i.e. arithmetic mean of $\delta^{13} \mathrm{C}$ and $\delta^{15} \mathrm{~N}$ per ensemble) for each pairwise combination of ensembles. Further, we assessed differences in ensemble dispersion within isotope space by 
testing whether (1) mean distances of singular species to ensemble centroids and (2) within-ensemble mean nearest-neighbour distances differ between each pairwise combination of ensembles. Using a residual permutation procedure (RPP), we compared all centroid location and dispersion metrics to null distributions. This procedure shuffles residual vectors of individual observations $\left(\delta^{13} \mathrm{C}-\right.$ $\delta^{15} \mathrm{~N}$ pair of one species) to the ensemble centroids and generates null model distributions based on 9999 random permutations of residual vectors (for details see Turner et al. 2010). The RPP allows for statistical testing of ensemble differences from zero, i.e. the null hypothesis of no difference between the pairs of ensembles. For differences between centroid locations, we calculated the parametric Hotelling's $\mathrm{T}^{2}$ test statistics, which is a multivariate analogue of the t-test. All calculations of centroid location and dispersion metric test statistics are based on Turner et al. (2010).

Third, we applied multivariate analysis, which incorporates within-species variation. Based on MANOVA, we test whether species differ in stable isotope signatures. Using univariate ANOVAs and subsequent post hoc Tukey HSD tests, we further examined whether these differences are due to interspecific variation in $\delta^{13} \mathrm{C}$ or $\delta^{15} \mathrm{~N}$ and whether species pairs differ from each other. In order to test whether the community is isotopically structured into ensembles, we ran further multivariate analyses (1) with ensemble as the only explanatory variable and (2) with ensemble, body mass and forearm length as covariates. Based on univariate ANOVAs, we further tested whether these differences are due to inter-ensemble variation in $\delta^{13} \mathrm{C}$ or $\delta^{15} \mathrm{~N}$ and used post hoc Tukey HSD tests to examine pairwise differences between ensembles. All statistics are performed in the statistical package $\mathrm{R}$ 2.15 (www.r-project.org) and tests were two-tailed with accepted significance levels of $\mathrm{P} \leq 0.05$.

\section{RESULTS}

\section{Plant and arthropod samples}

Plant and insect samples were analysed to provide a habitat baseline of isotopic variation. Plant samples $(n=3)$, collected at sites in the Ankarana in the immediate proximity to bat roosts, had a median of $\delta^{13} \mathrm{C}$ of $-31.2 \%$ (range $=-34.6 \%$ to $-30.7 \%$ ) and a median $\delta^{15} \mathrm{~N}$ of $4.0 \%$ (range $=2.8-4.2 \%$ ). Insect samples (small 0.5$1.0 \mathrm{~cm}$, including Diptera and Lepidoptera, $\mathrm{n}=41$ ) had a mean $( \pm \mathrm{SD}) \delta^{13} \mathrm{C}$ of $-25.0 \% \pm 1.54 \%$ and $\delta^{15} \mathrm{~N}$ of $7.3 \% \pm 2.7 \%$. Overall, insects showed high variation in both stable isotope ratios, supporting the assumption that isotopic differences between bat species reflect varying prey sources in their diet.

\section{Community overview}

We calculated several measures to describe the trophic community structure based on the $\delta^{13} \mathrm{C}-\delta^{15} \mathrm{~N}$ bi-plot of species mean values (Figure 1). The mean $\delta^{15} \mathrm{~N}$ of species in the Ankarana bat community was $9.8 \%$ and the total $\delta^{15} \mathrm{~N}$ range was $4.4 \%$; hence, the community spans two trophic levels from a $\delta^{15} \mathrm{~N}$ minimum of $6.8 \%$ for Rousettus madagascariensis, c. 3\% enriched towards the plants in the habitat, to a maximum of $11.2 \%$ for Triaenops auritus, c. $4 \%$ enriched towards the insects in the habitat. For $\delta^{13} \mathrm{C}$, the community mean was $-21.2 \%$ and the total range was $3.4 \%$, with a minimum of $-22.7 \%$ o for R. madagascariensis and a maximum of $-19.3 \%$ in Mormopterus jugularis, indicating that consumers include multiple basal resources with varying $\delta^{13} \mathrm{C}$ in their diets. The total stable isotope area covered by the community was $8.91 \%{ }^{2}$ based on convex hull and $5.83 \%{ }^{2}$ based on standard ellipse areas. The mean distance to the community centroid was $1.24 \%$ (range $=0.05-3.39 \%$ ) and the mean nearest-neighbour distance was $0.46 \%$ (range $=0.06-1.59 \%$ ). Species aggregation in the $\delta^{13} \mathrm{C}-$ $\delta^{15} \mathrm{~N}$ bi-plot was high $(\mathrm{R}=1.24)$, but nearest-neighbour distances did not deviate from a random pattern $(\mathrm{Z}=$ $1.85, \mathrm{P}=0.064)$. For the three cases of species groups of the same genus (Triaenops, Miniopterus and Chaerephon), a congener was never the nearest neighbour in the $\delta^{13} \mathrm{C}-$ $\delta^{15} \mathrm{~N}$ bi-plot and distances between pairs of congeners were larger than mean $+\mathrm{SD}$ of the nearest-neighbour distances $(0.86 \%)$. The exception is for $M$. griveaudi- $M$. gleni $(0.79 \%)$.

\section{Dispersion statistic}

The Euclidean distances between centroids of ensembles differed from zero for all pairwise comparisons of groups $(\mathrm{P}<0.05)$ (Table 1). The mean distances of individual species to the centroid of its ensemble did not differ significantly from zero for any pairwise comparison (all $\mathrm{P}>0.4$ ). Further, there were no differences for withingroup mean nearest-neighbour distances (all $\mathrm{P}>0.5$ ).

\section{Multivariate analysis}

Multivariate analysis revealed an effect of species $\left(\right.$ MANOVA, Pillai's trace $=1.09, \mathrm{~F}_{(15,156)}=6.3, \mathrm{P}<$ 0.0001). Overall, species differed in $\delta^{15} \mathrm{~N}\left(\mathrm{~F}_{(15,78)}=\right.$ 9.60, $\mathrm{P}<0.0001)$ and in $\delta^{13} \mathrm{C}\left(\mathrm{F}_{(15,78)}=4.58\right.$, $\mathrm{P}<0.0001$ ) (Figure 2). Post hoc pairwise comparisons showed differences only between some species pairs (Appendix 2). Notably, R. madagascariensis differed from all others in $\delta^{15} \mathrm{~N}($ all $\mathrm{P}<0.02)$, except Eidolon dupreanum. Eidolon dupreanum differed in $\delta^{15} \mathrm{~N}$ from all Miniopteridae 


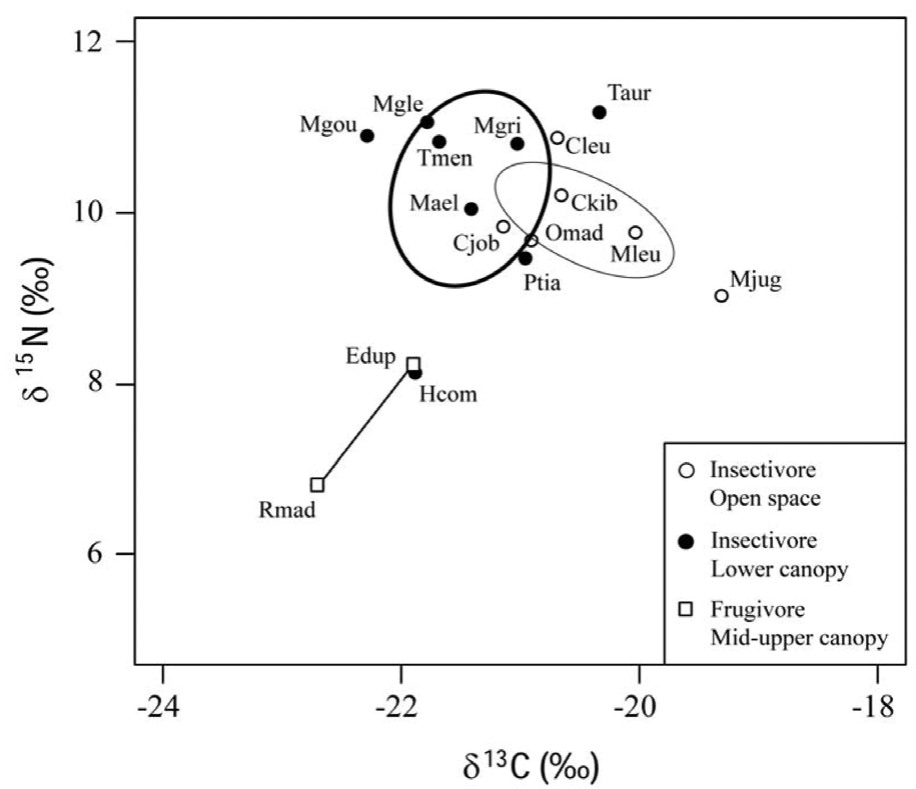

Figure 1. Mean $\delta^{13} \mathrm{C}$ and $\delta^{15} \mathrm{~N}$ of all bat species documented in Ankarana, northern Madagascar. Species belonging to the same ensemble are depicted in the same symbol. Ensembles are largely delineated standard ellipses (bold line: insectivore lower canopy, light line: insectivore openspace) or connected by a solid line (frugivore mid-upper canopy). Key to species - Edup: Eidolon dupreanum, Rmad: Rousettus madagascariensis, Hcom: Hipposideros commersoni, Taur: Triaenops auritus, Tmen: T. menamena, Ckib: Coleura kibomalandy, Ptia: Paremballonura tiavato, Cjob: Chaerephon jobimena, Cleu: C. leucogaster, Mleu: Mops leucostigma, Mjug: Mormopterus jugularis, Omad: Otomops madagascariensis, Mgou: Myotis goudoti, Mael: Miniopterus aelleni, Mglen: M. gleni, Mgri: M. griveaudi.

Table 1. Mean Euclidean distances between centroids of ensembles, mean Euclidean distances between individual species and centroid of its ensemble, and mean distances between nearest-neighbours within ensembles. Statistical difference from zero was assessed based on residual permutation procedure (RPP) with 9999 random permutations and using the multivariate parametric Hotelling's $\mathrm{T}^{2}$ test statistics. Ins-open: insectivore open space, Ins-low: insectivore lower canopy, Frug-mid: frugivore mid-upper canopy

\begin{tabular}{|c|c|c|c|c|}
\hline Guild pair & Mean distance & $\mathrm{P}$ value (RPP) & ${\text { Hotelling's } \mathrm{T}^{2}}^{2}$ & $\mathrm{P}$ \\
\hline \multicolumn{5}{|c|}{ Between-guild centroid distances } \\
\hline Ins-open-Ins-low & 1.05 & 0.015 & 8.7 & 0.044 \\
\hline Ins-open-Frug-mid & 3.05 & 0.001 & 52.1 & $<0.001$ \\
\hline Ins-low-Frug-mid & 2.95 & 0.001 & 39.2 & $<0.001$ \\
\hline \multicolumn{5}{|c|}{ Within-guild centroid distances } \\
\hline Ins-open-Ins-low & 0.25 & 0.423 & & \\
\hline Ins-open-Frug-mid & 0.07 & 0.889 & & \\
\hline Ins-low-Frug-mid & 0.19 & 0.754 & & \\
\hline \multicolumn{5}{|c|}{ Nearest-neighbour distances } \\
\hline Ins-open-Ins-low & 0.07 & 0.777 & & \\
\hline Ins-open-Frug-mid & 0.26 & 0.551 & & \\
\hline Ins-low-Frug-mid & 0.33 & 0.586 & & \\
\hline
\end{tabular}

(all $\mathrm{P}<0.01$ ), as well as Chaerephon leucogaster, Coleura kibomalandy, Triaenops auritus and T. menamena (all $\mathrm{P}<$ 0.05).

There were differences within families for $\delta^{15} \mathrm{~N}$, such as between Hipposideros commersoni and both Triaenops spp. (all $\mathrm{P}<0.001$ ). Across families, Mormopterus jugularis differed in $\delta^{15} \mathrm{~N}$ from Miniopterus gleni $(\mathrm{P}=$ 0.042), further H. commersoni differed from C. kibomalandy $(\mathrm{P}=0.035)$, as well as from Myotis goudoti $(\mathrm{P}<0.001)$, Miniopterus gleni $(\mathrm{P}<0.001)$ and M. griveaudi $(\mathrm{P}<$
0.001). For $\delta^{13} \mathrm{C}$ there were differences across families - Mormopterus jugularis differed from E. dupreanum (P = 0.002), R. madagascariensis ( $\mathrm{P}<0.0001)$, H. commersoni $(\mathrm{P}=0.002)$, T. menamena $(\mathrm{P}=0.008)$, Myotis goudoti $(\mathrm{P}<0.001)$, Miniopterus aelleni $(\mathrm{P}=0.033)$ and M. gleni $(\mathrm{P}=0.004)$. Further, R. madagascariensis differed in $\delta^{13} \mathrm{C}$ from T. auritus $(\mathrm{P}=0.007), \mathrm{C}$. kibomalandy $(\mathrm{P}=0.041)$ and Mormopterus jugularis $(\mathrm{P}<0.0001)$.

Also ensemble differed in isotopic signatures overall (MANOVA, Pillai's trace $=0.57, \mathrm{~F}_{(4,182)}=18, \mathrm{P}<$ 

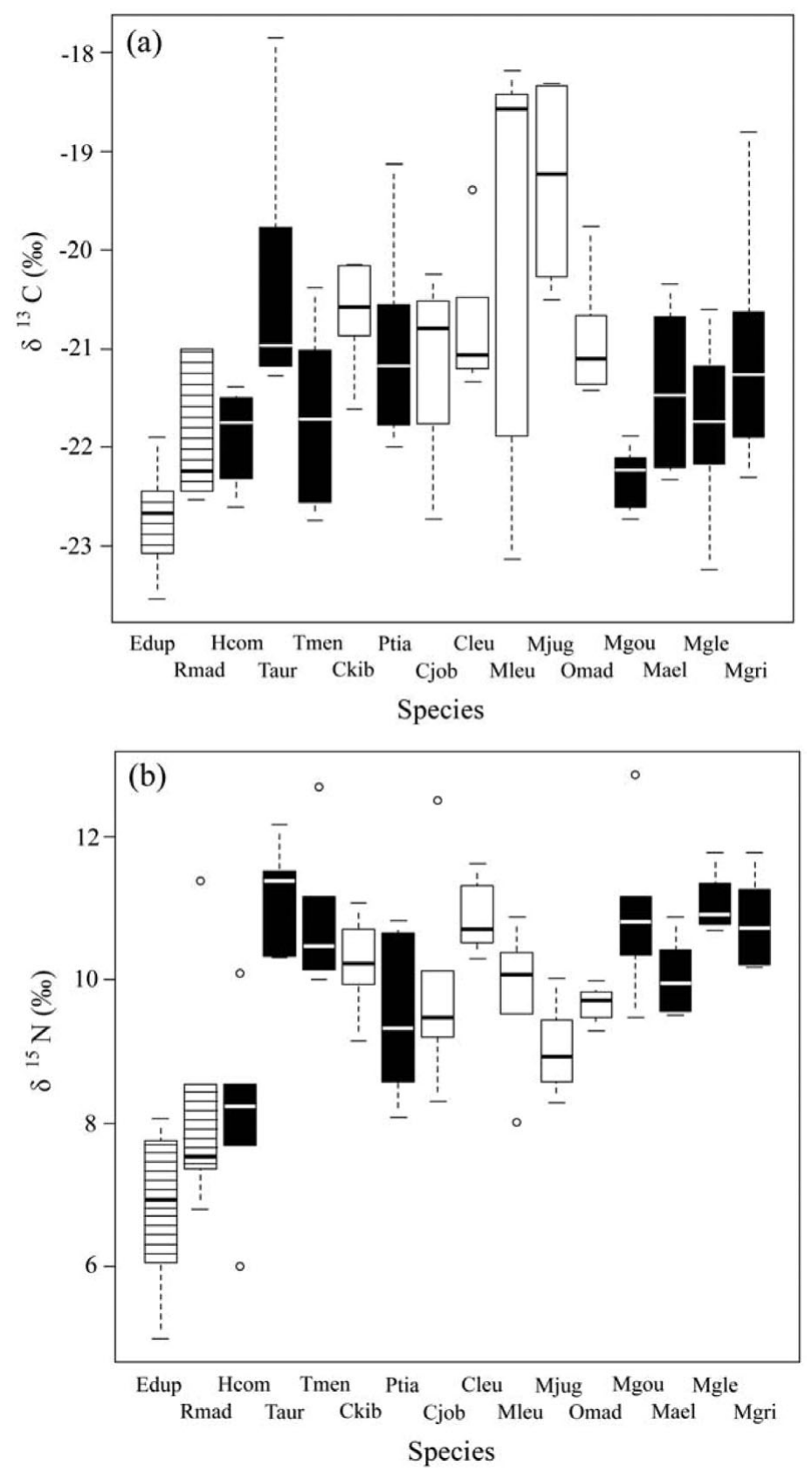

Figure 2. Differences in $\delta^{13} \mathrm{C}$ (a) and $\delta^{15} \mathrm{~N}$ (b) among 16 bat species co-occurring at Ankarana, northern Madagascar. Shown are median, interquartile range and range for $\mathrm{n}=6$ individuals per species, shadings indicate different ensembles (hatched: frugivore mid-upper canopy; black: insectivore open-space; white: insectivore low canopy). See Figure 1 for definition of species acronyms.

0.0001), as well as in $\delta^{15} \mathrm{~N}$ (univariate ANOVA, $\left.\mathrm{F}_{(2,91)}=25.2, \mathrm{P}<0.0001\right)$ and in $\delta^{13} \mathrm{C}\left(\mathrm{F}_{(2,91)}=15.0, \mathrm{P}<\right.$ $0.0001)$. Post hoc pairwise comparisons revealed that all ensemble pairs differed in $\delta^{13} \mathrm{C}$ (all $\mathrm{P}<0.05$ ). For $\delta^{15} \mathrm{~N}$, frugivorous mid- to upper-canopy species differed from insectivorous open-space and lower-canopy species (all $\mathrm{P}<0.0001$ ), but the two insectivore ensembles were similar $(\mathrm{P}=0.28)$. The inclusion of body mass and forearm length as additional explanatory variables helped to improve model fit $\left(\mathrm{F}_{(4,178)}=4.7, \mathrm{P}=0.001\right)$ - ensemble (Pillai's trace $\left.=0.62, \mathrm{~F}_{(4,178)}=19.8, \mathrm{P}<0.0001\right)$ and forearm length (Pillai's trace $=0.18, \mathrm{~F}_{(2,88)}=9.4, \mathrm{P}=$ 0.0002 ) explain significant parts of the variation but body mass was not significant (Pillai's trace $=0.02, \mathrm{~F}_{(2,88)}=$ $0.8, \mathrm{P}=0.44)$. Overall, the univariate models including species as the only predictor explained more variation $\left(\delta^{15} \mathrm{~N}: \mathrm{R}^{2}=0.65, \delta^{13} \mathrm{C}: \mathrm{R}^{2}=0.47\right)$ than models with ensemble as the only predictor $\left(\delta^{15} \mathrm{~N}: \mathrm{R}^{2}=0.36, \delta^{13} \mathrm{C}\right.$ : 
$\left.\mathrm{R}^{2}=0.25\right)$ and the covariance models $\left(\delta^{15} \mathrm{~N}: \mathrm{R}^{2}=0.45\right.$, $\delta^{13} \mathrm{C}: \mathrm{R}^{2}=0.29$ ).

\section{DISCUSSION}

In many tropical forest communities bats are the most species-rich mammalian order (Kingston 2009) and understanding mechanisms allowing their coexistence will provide important insights into community ecology. Classical niche theory (reviewed in Chase \& Leibold 2003), as well as random processes (Hubbell 2001), have only been able to partially explain the structure and composition in New and Old World bat assemblages (Bloch et al. 2011, Schoeman \& Jacobs 2011, Stevens \& Willig 2000). However, these assemblages are often structured into distinct trophic guilds (Giannini \& Kalko 2004), with partitioning of species along habitat dimensions based on ecosensory and morphological adaptations (summarized in Schnitzler et al. 2003). Here, we used stable isotope analysis to provide the first insights into the trophic structure of a species-rich Malagasy bat assemblage and possible mechanisms for facilitating the local coexistence of taxa.

Assuming an average trophic enrichment of 3\%o per trophic level (Vanderklift \& Ponsard 2003), we found that the Ankarana bat assemblage spans two trophic levels with the frugivorous/nectarivorous species Rousettus madagascariensis and Eidolon dupreanum representing the primary consumers. These species are largely distinct from all others at Ankarana in $\delta^{15} \mathrm{~N}$ and the exceptions are best explained by sample size and notable withinspecies variation. Most important in this regards, is the largest insectivorous species, Hipposideros commersoni, which falls in the same trophic level and is distinct in $\delta^{15} \mathrm{~N}$ from many of the smaller insectivorous bats. This species specializes on Coleoptera, particularly scarabids (Rakotoarivelo et al. 2007, 2009; Razakarivony et al. 2005). All other insectivorous taxa form a diverse secondary-consumer level, which is on average $4 \%$ enriched over the primary level.

Other tropical bat assemblages typically enclose representatives of phytophagous and animalivorous species (Giannini \& Kalko 2004); however, distinct trophic levels are not always found. For example, in a diverse New World assemblage of 67 members of the Phyllostomidae, stable nitrogen isotope analysis revealed that species ranged continuously over three trophic levels including herbivorous, insectivorous and carnivorous/sanguinivorous (Rex et al. 2010). Thus, accordingly, the coexistence of bat species at Ankarana can partly be explained by avoidance of feeding competition at different trophic levels.

At Ankarana, species of different ensembles formed distinct clusters in isotopic space. The frugivorous mid-canopy bats were distinct in both isotopes. The insectivorous above canopy/open space bats differed from insectivorous low-canopy bats only in $\delta^{13} \mathrm{C}$. This pattern is in accordance with the prediction of the canopyeffect hypothesis, which posits that $\delta^{13} \mathrm{C}$ in forest plants generally increases as a function of distance from the ground (Medina \& Minchin 1980). Similar patterns of $\delta^{13} \mathrm{C}$ and vertical stratification in feeding height have been revealed in Neotropical bats (Rex et al. 2011, Voigt 2010) and forest-dwelling rodents (Mauffrey \& Catzeflis 2003), a Malagasy tenrec and rodent community (Dammhahn et al. 2013) and a complete mammal community in the Congo Basin (Cerling et al. 2004). Thus, the partitioning of microhabitats among insectivorous bat species is a further mechanism decreasing feeding competition and facilitating the coexistence of species with similar diets.

In contrast to our prediction, species utilizing the same microhabitat did not show indications of stronger trophic differentiation than those occupying different microhabitats. Thus, based on stable isotopes these bat species appear to have similar dietary composition. The two frugivorous/nectarivorous species (Eidolon dupreanum and Rousettus madagascariensis) are similar in isotopic signatures. However, these two species differ notably in size ( $342 \mathrm{~g}$ versus $55 \mathrm{~g}$ body mass, respectively) and are, thus, not expected to show strong feeding competition (Hutchinson 1957). Studies of these two taxa in eastern Madagascar revealed that they differ notably in the maximal size of seeds they ingest $-E$. dupreanum swallows seeds up to $7 \mathrm{~mm}$ and feeds almost exclusively on fruits (Picot et al. 2007, Ratrimomanarivo 2007) and R. madagascariensis up to $2.5 \mathrm{~mm}$, particularly Ficus fruits, and extensively consumes nectar, flowers and leaves (Andrianaivoarivelo et al. 2011). Excluding the poorly known emballonurid Coleura kibomalandy, five species of molossid represent the open-space/abovecanopy insectivore ensemble in Ankarana. These taxa, which are largely similar in body size (Appendix 1), use narrow-band echolocation to locate large flying insects in clutter-free space and are similar in $\delta^{15} \mathrm{~N}$ and $\delta^{13} \mathrm{C}$. Faecal analyses of molossids in eastern Madagascar revealed that they principally feed on Coleoptera, Hemiptera, Lepidoptera and Diptera, with differences in the proportion of different insect groups in the diet of some species (Andrianaivoarivelo et al. 2006). In particular, Mormopterus jugularis consumed higher proportions of Coleoptera (61\%) than Mops leucostigma (40\%), but with considerable seasonal variation. On the basis of faecal analyses of individuals captured in another Malagasy dry-forest formation, the largest molossid in the Ankarana sample, Otomops madagascariensis, feeds extensively on Coleoptera and Lepidoptera (> 80\%) (Andriafidison et al. 2007). The low-canopy insectivores are the most species-rich ensemble in the Ankarana 
bat assemblage, comprising members of four different families and eight different species (Appendix 1). With the exception of H. commersoni, these taxa are very similar in stable isotopes and range in body mass from 3.3 to $13 \mathrm{~g}$ with several similarly sized species pairs. Thus, in the Ankarana bat assemblage, niche segregation, as measured by body size or stable isotope variation, does not appear to explain the co-occurrence of the molossid species, as well as of the low-canopy insectivores. Further studies on the feeding ecology of these syntopic species are needed to understand finer details on potential dietary overlap.

Also at the community level, we found only some indication for resource partitioning across species. The conservative post hoc tests differentiated the speciesspecific isotopic signatures of a few species pairs. Moreover, the community-level analyses based on the bi-plot metrics revealed that the Ankarana assemblage is densely packed in isotope space with many species having similar diets (Layman et al. 2007), indicating that competitive trophic interactions only partly structure this assemblage.

Theoretically, it has been proposed that congeneric species experience higher competition due to recent ancestry and resulting similarities in ecology, morphology and behaviour (Sfenthourakis et al. 2005). Our results did not support this pattern for the three congeneric species groups in the Ankarana bat assemblage (Appendix 1): (1) Chaerephon was represented by two species, which were similar in isotopic signatures, but differ in body mass and forearm length. The size difference renders increased congeneric feeding competition unlikely between these two species. (2) Three species of Miniopterus co-occur at Ankarana and details of ecological niche partitioning are not known. Miniopterus gleni, the largest, exceeds the other species by c. $30 \%$ in forearm length and is more than double in body mass. Thus, reduced feeding competition with the other two coexisting species is expected (Hutchinson 1957). In contrast, M. aelleni and $M$. griveaudi are similar in body size and mass but cooccur at various sites in Madagascar and the Comoros (Goodman 2011). Ramasindrazana et al. (2011) showed that $M$. aelleni deviates from the allometric relationship between forearm length and peak frequency within the Miniopteridae, which might indicate echolocation character displacement. Our results indicate that in sympatry M. aelleni and M. griveaudi do not take different arthropod prey based on $\delta^{15} \mathrm{~N}$ and $\delta^{13} \mathrm{C}$ signatures (Figure 2). (3) Our sample included two species of Triaenops, T. auritus and T. menamena, similar in size and stable isotopic signatures. Faecal analyses of $T$. furculus, sister species to T. auritus, and T. menamena at a spiny bush site in south-western Madagascar, indicate that they forage in largely the same microhabitats and show broad overlap in the orders of insects they consume, but with some notable seasonal differences (Ramasindrazana et al. 2012). Since these two species are distinct in the peak frequency of their largely constantfrequency calls, differentiation of prey based on size is likely (Ramasindrazana \& Goodman 2012).

Stable isotope studies are limited in resolution of dietary composition of the study animal and are based on the assumption that prey sources differ isotopically. Potential insect prey collected at Ankarana showed high variation in both stable isotopes lending further support to this assumption. Thus, low isotopic differentiation of bat species within the Ankarana assemblage can be interpreted as an indication of reduced feeding competition. This conclusion corresponds to similar studies (Stevens \& Willig 2000), which also found low support for competitive interactions in the structuring of bat assemblages. Likewise, combining data on morphology and echolocation in Old World bat assemblages, Schoeman \& Jacobs (2011) found higher dietary overlap between species within ensembles than expected by chance. Several non-exclusive causes have been presented to explain this apparent deviation from fundamental predictions of ecological niche theory. First, bat assemblages might not reach equilibrium states, because population densities of a given species may be too low (Bloch et al. 2011). Second, food might not be a limiting resource for insectivorous bats (Fenton 1990), partly because their mobile nature allows them to be more flexible to resource density, size and distribution and, thus, relax local resource competition (Stevens \& Willig 2000). Third, specific combinations of phenotypic characteristics of bats, such as body size, cranial and wing morphology, and echolocation calls, facilitate a variety of dietary specializations (Aguirre et al. 2002, Norberg 1994, Schnitzler et al. 2003, Siemers \& Schnitzler 2004). These different causes could potentially explain the relaxed feeding competition in the Ankarana assemblage.

In conclusion, stable isotopes as an indirect measure of niche differentiation provided some insights into the community ecology of a bat assemblage in northern Madagascar. A combination of mechanisms appeared to facilitate the coexistence of these species: (1) differentiation into two trophic levels and (2) utilization of different microhabitats by insectivorous bats. In contrast to other non-volant mammalian communities (Dammhahn \& Kappeler 2013, Dammhahn et al. 2013), community-wide trophic avoidance among species was less pronounced. This observation is in accordance with other studies of a variety of New and Old World bat assemblages (Schoeman \& Jacobs 2011, Stevens \& Willig 2000), based on different types of data, indicating that competitive interactions appear to be relaxed in the different communities and not a prevailing structuring force. Illuminating alternative mechanisms by studying fine-scale dietary specializations, habitat use, 
ecomorphology and sensory ecology at local and islandwide scales will be fascinating areas of further research on the bats of Madagascar.

\section{ACKNOWLEDGEMENTS}

We thank the Ministère des Forêts et de l'Environnement for providing research authorizations for the capture and collection of animals. The fieldwork was supported by grants from the National Geographic Society (663799 \& 7402-03), The Volkswagen Foundation and The John D. and Catherine T. MacArthur Foundation. Scott Cardiff, Fanja Ratrimomanarivo, Beza Ramasindrazana, Corrie Schoeman and Peter Taylor helped with some of the fieldwork. We thank Peter M. Kappeler for support and Reinhard Langel (KOSI) for technical help in the lab. Financial support for the isotope analysis was kindly provided by Deutsches Primatenzentrum Göttingen and The Volkswagen Foundation. An earlier version of this manuscript benefited from comments by two anonymous reviewers.

\section{LITERATURE CITED}

AGUIRRE, L. F., HERREL, A., VANDAMME, R. \& MATTHYSEN, E. 2002. Ecomorphological analysis of trophic niche partitioning in a tropical savannah bat community. Proceedings of the Royal Society of London Series B 269:1271-1278.

AGUIRRE, L. F., HERREL, A., VANDAMME, R. \& MATTHYSEN, E. 2003. The implications of food hardness for diet in bats. Functional Ecology 17:201-212.

ANDRIAFIDISON, D., KOFOKY, A., MBOHOAHY, T., RACEY, P. A. \& JENKINS, R. K. B. 2007. Diet, reproduction and roosting habits of the Madagascar free-tailed bat, Otomops madagascariensis Dorst, 1953 (Chiroptera: Molossidae). Acta Chiropterologica 9:445-450.

ANDRIANAIVOARIVELO, R. A., RANAIVOSON, N., RACEY, P. A. \& JENKINS, R. K. B. 2006. The diet of three synanthropic bats (Chiroptera: Molossidae) from eastern Madagascar. Acta Chiropterologica 8:439-444.

ANDRIANAIVOARIVELO, R. A., RAMILIJAONA, O. R., RACEY, P. A., RAZAFINDRAKOTO, N. \& JENKINS, R. K. B. 2011. Feeding ecology, habitat use and reproduction of Rousettus madagascariensis Grandidier, 1928 (Chiroptera: Pteropodidae) in eastern Madagascar. Mammalia 75:69-78.

BLOCH, C. P., STEVENS, R. D. \& WILLIG, M. R. 2011. Body size and resource competition in New World bats: a test of spatial scaling laws. Ecography 34:460-468.

CARDIFF, S. G. 2006. Bat cave selection and conservation at Ankarana, northern Madagascar. MA thesis, Columbia University, New York. $65 \mathrm{pp}$.

CARDIFF, S. G. \& BEFOUROUACK, J. 2003. The Réserve Spéciale d'Ankarana. Pp. 1501-1507 in Goodman, S. M. \& Benstead, J. P. (eds.). The natural history of Madagascar. University of Chicago Press, Chicago.

CERLING, T. E., HART, J. A. \& HART, T. B. 2004. Stable isotope ecology in the Ituri Forest. Oecologia 138:5-12.

CHASE, J. M. \& LEIBOLD, M. A. 2003. Ecological niches. Linking classical and contemporary approaches. University of Chicago Press, Chicago. $212 \mathrm{pp}$.

CLARK, P. J. \& EVANS, F. C. 1954. Distance to nearest neighbor as a measure of spatial relationships in populations. Ecology 35:445-453.

DAMMHAHN, M. \& KAPPELER, P. M. (2013). Stable isotope analyses reveal dense trophic species packing and clear niche differentiation in a Malagasy primate community. American Journal of Physical Anthropology. doi: 10.1002/ajpa.22426.

DAMMHAHN, M., SOARIMALALA, V. \& GOODMAN, S. M. 2013. Trophic niche differentiation and microhabitat utilization in a species-rich montane forest small mammal community of eastern Madagascar. Biotropica 45:111-118.

DENIRO, M. J. \& EPSTEIN, S. 1978. Influence of diet on the distribution of carbon isotopes in animals. Geochimica et Cosmochimica Acta 42:495506.

DENIRO, M. J. \& EPSTEIN, S. 1981. Influence of diet on the distribution of nitrogen isotopes in animals. Geochimica et Cosmochimica Acta 45:341-351.

EGGERS, T. \& JONES, T. H. 2000. You are what you eat ... or are you? Trends in Ecology and Evolution 15:265-266.

FENTON, M. B. 1990. The foraging behaviour and ecology of animaleating bats. Canadian Journal of Zoology 68:411-422.

FLEMING, T. H., NUNEZ, R. A. \& STERNBERG, L. S. L. 1993. Seasonal changes in the diets of migrant and non-migrant nectarivorous bats as revealed by carbon stable isotope analysis. Oecologia 94:72-75.

GIANNINI, N. P. \& KALKO, E. K. V. 2004. Trophic structure in a large assemblage of phyllostomid bats in Panama. Oikos 105:209-220.

GOODMAN, S. M. 2011. Les chauves-souris de Madagascar. Association Vahatra, Antananarivo. $129 \mathrm{pp}$.

GOODMAN, S. M., ANDRIAFIDISON, D., ANDRIANAIVOARIVELO, R., CARDIFF, S. G., IFTICENE, E., JENKINS, R. K. B., KOFOKY, A., MBOHOAHY, T., RAKOTONDRAVONY, D., RANIVO, J., RATRIMOMANARIVO, F., RAZAFIMANAHAKA, J. \& RACEY, P. A. 2005. The distribution and conservation of bats in the dry regions of Madagascar. Animal Conservation 8:153-165.

GOODMAN, S. M., CARDIFF, S. G., RANIVO, J., RUSSELL, A. L. \& YODER, A. D. 2006. A new species of Emballonura (Chiroptera: Emballonuridae) from the dry regions of Madagascar. American Museum Novitates 3538:1-24.

GOODMAN, S. M., RAMASINDRAZANA, B., MAMINIRINA, C. P., SCHOEMAN, M. C. \& APPLETON, B. 2011. Morphological, bioacoustical, and genetic variation in Miniopterus bats from eastern Madagascar, with the description of a new species. Zootaxa 2880:119.

GOODMAN, S. M., TAYLOR, P. J., RATRIMOMANARIVO, F. \& HOOFER, S. 2012a. The genus Neoromicia (Family Vespertilionidae) in Madagascar, with the description of a new species. Zootaxa 3250:125.

GOODMAN, S. M., PUECHMAILLE, S. J., FRIEDLI-WEYENETH, N., GERLACH, J., RUEDI, M., SCHOEMAN, M. C., STANLEY, W. T. \& 
TEELING, E. C. 2012b. Phylogeny of emballonurini bats (Family Emballonuridae): new genus and new species of Emballonuridae from Madagascar. Journal of Mammalogy 93:1440-1455.

HERRERA, L. G., HOBSON, K. A., MANZO, A, A., ESTRADA, B, D., SÁNCHEZ-CORDERO, V. \& MÉNDEZ, C, G. 2001. The role of fruits and insects in the nutrition of frugivorous bats: evaluating the use of stable isotope models. Biotropica 33:520-528.

HERRERA, L. G., GUTIERREZ, E., HOBSON, K. A., ALTUBE, B., DIAZ, W. G. \& SANCHES-CORDERO, V. 2002. Sources of assimilated protein in five species of New World frugivorous bats. Oecologia 133:280-287.

HUBBELL, S. P. 2001. The unified neutral theory of species abundance and diversity. Princeton University Press, Princeton. 448 pp.

HUTCHINSON, G. E. 1957. Concluding remarks. Cold Spring Harbor Symposium. Quantitative Biology 22:415-427.

JACKSON, A. L., INGER, R., PARNELL, A. C. \& BEARHOP, S. 2011. Comparing isotopic niche widths among and within communities. SIBER - Stable Isotope Bayesian Ellipses in R. Journal of Animal Ecology 80:595-602.

KINGSTON, T. 2009. Analysis of species diversity of bat assemblages. Pp. 158-176 in Kunz, T. H. \& Parsons, S. (eds.). Ecological and behavioral methods for the study of bats. The Johns Hopkins University Press, Baltimore.

KREBS, C. J. 1998. Ecological methodology. Addison-Welsey Educational Publishers, Menlo Park. 654 pp.

LAYMAN, C. A., ARRington, D. A., MONTANA, C. G. \& POST, D. M. 2007. Can stable isotope ratios provide for community-wide measures of trophic structure? Ecology 88:42-48.

MAUFFREY, J. F. \& CATZEFLIS, F. 2003. Ecological and isotopic discrimination of syntopic rodents in a Neotropical forest of French Guiana. Journal of Tropical Ecology 19:209-214.

MCCUTCHAN, J. H., LEWIS, W. M., KENDALL, C. \& MCGRATH, C. C. 2003. Variation in trophic shift for stable isotope ratios of carbon, nitrogen, and sulfur. Oikos 102:378-390.

MEDINA, E. \& MINCHIN, P. 1980. Stratification of $\delta^{13} \mathrm{C}$ values of leaves in Amazonian rain forests. Oecologia 45:377-378.

NORBERG, U. M. 1994. Wing design, flight performance, and habitat use in bats. Pp. 205-239 in Wainwright, P. C. \& Reilly, S. M. (eds.). Ecological morphology. Integrative organismal biology. University of Chicago Press, Chicago.

PETERSON, R. L., EGER, J. L. \& MITCHELL, L. 1995. Chiroptères. Faune de Madagascar volume 84. Muséum national d'Histoire naturelle, Paris. 204 pp.

PICOT, M., JENKINS, R. K. B., RAMILIJAONA, O., RACEY, P. A. \& CARRIÈRE, S. M. 2007. The feeding ecology of Eidolon dupreanum (Pteropodidae) in eastern Madagascar. African Journal of Ecology 45:645-650.

RAKOTOARIVELO, A. A., RANAIVOSON, N., RAMILIJAONA, O., R., KOFOKY, A. F., RACEY, P. A. \& JENKINS, R. K. B. 2007. Seasonal food habits of five sympatric forest microchiropterans in western Madagascar. Journal of Mammalogy 88:959-966.

RAKOTOARIVELO, A. A., RALISATA, M., RAMILIJAONA, O., R., RAKOTOMALALA, M. R., RACEY, P. A. \& JENKINS, R. K. B. 2009. The food habits of a Malagasy giant: Hipposideros commersoni (E. Geoffroy, 1813). African Journal of Ecology 47:283-288.
RAMASINDRAZANA, B. \& GOODMAN, S. M. 2012. Bio-écologie des chauves-souris du Parc National de Tsimanampetsotsa. 1. Identification bioacoustique et habitat préférentiel. Malagasy Nature 6:103-116.

RAMASINDRAZANA, B., GOODMAN, S. M., SCHOEMAN, M. C. \& APPLETON, B. 2011. Identification of cryptic species of Miniopterus bats (Chiroptera: Miniopteridae) from Madagascar and the Comoros using bioacoustics overlaid on molecular genetic and morphological characters. Biological Journal of the Linnean Society 104:284302.

RAMASINDRAZANA, B., RAJEMISON, B. \& GOODMAN, S. M. 2012. Bio-écologie des chauves-souris de Parc National de Tsimanampetsotsa. 2. Variation interspécifique et saisonnière du régime alimentaire. Malagasy Nature 6:117-124.

RATRIMOMANARIVO, F. H. 2007. Etude du régime alimentaire d'Eidolon dupreanum (Chiroptera: Pteropodidae) dans la région anthropisée des Hautes Terres du centre de Madagascar. Revue d'Ecologie (Terre Vie) 62:229-244.

RAZAKARIVONY, V. R., RAJEMISON, B. \& GOODMAN, S. M. 2005. The diet of Malagasy Microchiroptera based on stomach contents. Mammalian Biology 70:312-316.

REX, K., KELM, D. H., WIESNER, K., KUNZ, T. H. \& VOIGT, C. C. 2008. Species richness and structure of three Neotropical bat assemblages. Biological Journal of the Linnean Society 94:617629.

REX, K., CZACZKES, B. I., MICHENER, R., KUNZ, T. H. \& VOIGT, C. C. 2010. Specialization and omnivory in diverse mammalian assemblages. Ecoscience 17:37-46.

REX, K., MICHENER, R., KUNZ, T. H. \& VOIGT, C. C. 2011. Vertical stratification of Neotropical leaf-nosed bats (Chiroptera: Phyllostomidae) revealed by stable carbon isotopes. Journal of Tropical Ecology 27:211-222.

SCHNITZLER, H. U., MOSS, C. F. \& DENZINGER, A. 2003. From spatial orientation to food acquisition in echolocating bats. Trends in Ecology and Evolution 18:386-394.

SCHOEMAN, M. C. \& JACOBS, D. 2011. The relative influence of competition and prey defences on the trophic structure of animalivorous bat ensembles. Oecologia 166:493506.

SFENTHOURAKIS, S., TZANATOS, E. \& GIOKAS, S. 2005. Species cooccurrence: the case of congeneric species and a causal approach to patterns of species associations. Global Ecology and Biogeography 15:39-49.

SIEMERS, B. M. \& SCHNITZLER, H. U. 2004. Echolocation signals reflect niche differentiation in five sympatric congeneric bat species. Nature 429:657-661.

STEVENS, R. D. \& WILLIG, M. R. 2000. Density compensation in New World bat communities. Oikos 89:367-377.

TURNER, T. F., COLLYER, M. L. \& KRABBENHOFT, T. J. 2010. A general hypothesis-testing framework for stable isotope ratios in ecological studies. Ecology 91:2227-2233.

VANDERKLIFT, M. A. \& PONSARD, S. 2003. Sources of variation in consumer-diet $\delta^{15} \mathrm{~N}$ enrichment: a meta-analysis. Oecologia 136:169-182. 
VOIGT, C. C. 2010. Insights into strata use of forest animals using the 'canopy effect'. Biotropica 42:634-637.

VOIGT, C. C. \& KELM, D. H. 2006. Host preferences of the common vampire bat Desmodus rotundus assessed by stable isotopes. Journal of Mammalogy 87:1-6.

VOIGT, C.C., REX, K., MICHENER, R. \& SPEAKMAN, J. R. 2008. Nutrient routing in omnivorous animals tracked by stable carbon isotopes in tissue and exhaled breath. Oecologia 157:31-40.
VOIGT, C. C., KELM, D. H., BRADLEY, B. J. \& ORTMANN, S. 2009. Dietary analysis of plant-visiting bats. Pp. 593-609 in Kunz, T. H. \& Parsons, S. (eds.). Ecological and behavioral methods for the study of bats. The Johns Hopkins University Press, Baltimore.

WHITAKER, J. O., MCCRACKEN, G. F. \& SIEMERS, B. M. 2009. Food habits analysis of insectivorous bats. Pp. 567-592 in Kunz, T. H. \& Parsons, S. (eds.). Ecological and behavioral methods for the study of bats. The Johns Hopkins University Press, Baltimore. 
Appendix 1. Collection dates and sample size (n) of hair samples obtained from 94 specimens of all 16 bat species of the Ankarana assemblage included in the stable isotope analyses. Species marked by an asterisk $(*)$ are endemic to Madagascar and those with a plus (+) endemic to the Malagasy Region (Madagascar and the Comoros Archipelago). Information on foraging habitat, diet, body mass (BM) and forearm length (FL) of bat species are largely from Goodman (2011). In cases of species showing sexual dimorphism, we have used the mean body mass value of the two sexes.

\begin{tabular}{|c|c|c|c|c|c|}
\hline Species & Collection date (n) & $\mathrm{BM}(\mathrm{g})$ & $\mathrm{FL}(\mathrm{mm})$ & Foraging habitat & Diet \\
\hline \multicolumn{6}{|l|}{ Pteropodidae } \\
\hline *Eidolon dupreanum (Pollen, 1866) & $\begin{array}{l}27 \text { January } 2001(1) \\
15 \text { May } 2003(1) \\
1 \text { July } 2003(2) \\
1 \text { November } 2010(1)\end{array}$ & 342 & 133 & $\begin{array}{l}\text { Mid- to upper-canopy in forest and trees } \\
\text { growing in open areas }\end{array}$ & Fruits and occasionally nectar and pollen \\
\hline $\begin{array}{l}\text { *Rousettus madagascariensis (G. } \\
\text { Grandidier, 1928) }\end{array}$ & $\begin{array}{l}26 \text { January } 2001 \text { (1) } \\
15 \text { May } 2003(3) \\
21 \text { June } 2003(2)\end{array}$ & 55 & 72 & $\begin{array}{l}\text { Mid- to upper-canopy in forest and trees } \\
\text { growing in open areas }\end{array}$ & Fruits and occasionally nectar and pollen \\
\hline \multicolumn{6}{|l|}{ Hipposideridae } \\
\hline $\begin{array}{l}\text { *Hipposideros commersoni (E. Geoffroy, } \\
\text { 1803) }\end{array}$ & $\begin{array}{l}22 \text { January } 2001(2) \\
17-24 \text { May } 2003(4)\end{array}$ & 59 & 91 & $\begin{array}{l}\text { Lower one-half of forest and perhaps in } \\
\text { partially open areas }\end{array}$ & $\begin{array}{l}\text { Insectivore and perhaps occasionally on } \\
\text { small vertebrates }\end{array}$ \\
\hline *Triaenops auritus (G. Grandidier, 1912) & $\begin{array}{l}17 \text { May } 2003 \text { (1) } \\
\text { 3-12 July } 2004(5)\end{array}$ & 6.2 & 48 & Lower portion of forest & Insectivore \\
\hline $\begin{array}{l}\text { *Triaenops menamena (Goodman \& } \\
\text { Ranivo, 2009) } \\
\text { Emballonuridae }\end{array}$ & 13-17 May 2003 (6) & 8.5 & 51 & Lower portion of forest & Insectivore \\
\hline $\begin{array}{l}\text { *Coleura kibomalandy (Goodman et al., } \\
\text { 2012) }\end{array}$ & $\begin{array}{l}7-12 \text { July } 2004(3) \\
2 \text { November } 2010(3)\end{array}$ & 10 & 51 & $\begin{array}{l}\text { Not documented, but presumably in open } \\
\text { areas or open forest }\end{array}$ & Insectivore \\
\hline $\begin{array}{l}\text { *Paremballonura tiavato (Goodman et al., } \\
\text { 2006) } \\
\text { Molossidae }\end{array}$ & 9-17 May 2003 (6) & 3.3 & 37 & Lower portion of forest & Insectivore \\
\hline $\begin{array}{l}\text { *Chaerephon jobimena (Goodman \& Cardiff, } \\
\text { 2004) }\end{array}$ & $\begin{array}{l}15-25 \text { May } 2003(2) \\
25 \text { June } 2005(4)\end{array}$ & 14 & 46 & Open areas and above forest canopy & Insectivore \\
\hline $\begin{array}{l}\text { Chaerephon leucogaster (A. Grandidier, } \\
1870 \text { ) }\end{array}$ & 23 May 2003 (5) & 7.5 & 35 & Open areas and above forest canopy & Insectivore \\
\hline +Mops leucostigma (G. M. Allen, 1918) & $\begin{array}{l}23 \text { May } 2003(3) \\
1 \text { June } 2004(3)\end{array}$ & 21 & 44 & Open areas and above forest canopy & Insectivore \\
\hline *Mormopterus jugularis (Peters, 1865) & 19 May $2003(6)$ & 11 & 37 & Open areas and above forest canopy & Insectivore \\
\hline *Otomops madagascariensis (Dorst, 1953) & $\begin{array}{l}\text { 15-16 May } 2003(3) \\
8 \text { June } 2003(1) \\
28 \text { June } 2004(2)\end{array}$ & 24 & 62 & Open areas and above forest canopy & Insectivore \\
\hline \multicolumn{6}{|l|}{ Vespertilionidae } \\
\hline *Myotis goudoti (A. Smith, 1834) & $\begin{array}{l}\text { 11-18 May } 2003 \text { (5) } \\
3 \text { July } 2004 \text { (1) }\end{array}$ & 6.0 & 39 & $\begin{array}{l}\text { Lower portion of forest structure and in } \\
\text { partially open areas }\end{array}$ & Insectivore \\
\hline $\begin{array}{l}\text { Miniopteridae } \\
+ \text { Miniopterus aelleni (Goodman et al., } \\
\text { 2009) }\end{array}$ & 11-16 May 2003 (6) & 4.6 & 38 & $\begin{array}{l}\text { Lower portion of forest structure and in } \\
\text { partially open areas }\end{array}$ & Insectivore \\
\hline $\begin{array}{l}\text { * Miniopterus gleni (Peterson, Eger \& } \\
\quad \text { Mitchell, 1995) }\end{array}$ & $\begin{array}{l}\text { 15-18 May } 2003(4) \\
8 \text { June } 2003(1) \\
3 \text { July } 2004(1)\end{array}$ & 13.2 & 48 & $\begin{array}{l}\text { Lower portion of forest structure and in } \\
\text { partially open areas }\end{array}$ & Insectivore \\
\hline +Miniopterus griveaudi (Harrison, 1959) & $\begin{array}{l}15 \text { May } 2003(1) \\
\text { 3-18 July } 2004(4) \\
18 \text { June } 2005(1)\end{array}$ & 5.4 & 37 & $\begin{array}{l}\text { Lower portion of forest structure and in } \\
\text { partially open areas }\end{array}$ & Insectivore \\
\hline
\end{tabular}


APPENDIX 2. Results of post hoc Tukey HSD test for pairwise comparisons between all species. Shown are P-values: upper right for $\delta^{15} \mathrm{~N}$, and lower left for $\delta^{13} \mathrm{C}$. See Figure 1 for definition of species acronyms.

\begin{tabular}{|c|c|c|c|c|c|c|c|c|c|c|c|c|c|c|c|c|}
\hline Species & Edup & Rmad & Hcom & Taur & Tmen & Ckib & Ptia & Cjob & Cleu & Mleu & Mjug & Omad & Mgou & Mael & Mgle & Mgri \\
\hline Edup & & 0.50 & 1.00 & $<0.001$ & 0.001 & 0.046 & 0.67 & 0.23 & 0.002 & 0.37 & 0.98 & 0.41 & $<0.001$ & 0.10 & $<0.001$ & 0.002 \\
\hline Rmad & 0.99 & & 0.57 & $<0.0001<$ & $<0.0001$ & $<0.0001$ & 0.001 & $<0.0001$ & $<0.0001$ & $<0.001$ & 0.015 & $<0.001$ & $<0.0001$ & $<0.0001$ & $<0.0001$ & $<0.0001$ \\
\hline Hcom & 1.00 & 0.98 & & $<0.0001$ & 0.001 & 0.035 & 0.60 & 0.19 & 0.001 & 0.32 & 0.97 & 0.35 & $<0.001$ & 0.08 & $<0.001$ & 0.001 \\
\hline Taur & 0.31 & 0.007 & 0.34 & & 1.00 & 0.94 & 0.18 & 0.59 & 1.00 & 0.58 & 0.024 & 0.37 & 1.00 & 0.82 & 1.00 & 1.00 \\
\hline Tmen & 1.00 & 0.91 & 1.00 & 0.57 & & 0.99 & 0.56 & 0.94 & 1.00 & 0.92 & 0.13 & 0.80 & 1.00 & 0.99 & 1.00 & 1.00 \\
\hline Ckib & 0.69 & 0.041 & 0.72 & 1.00 & 0.91 & & 0.99 & 1.00 & 1.00 & 0.99 & 0.76 & 1.00 & 1.00 & 1.00 & 0.98 & 1.00 \\
\hline Ptia & 0.95 & 0.17 & 0.96 & 1.00 & 1.00 & 1.00 & & 1.00 & 0.55 & 1.00 & 1.00 & 1.00 & 0.44 & 1.00 & 0.27 & 0.57 \\
\hline Cjob & 0.99 & 0.32 & 0.99 & 0.99 & 0.99 & 1.00 & 1.00 & & 0.93 & 1.00 & 0.99 & 1.00 & 0.88 & 1.00 & 0.72 & 0.94 \\
\hline Cleu & 0.80 & 0.08 & 0.82 & 1.00 & 0.95 & 1.00 & 1.00 & 0.99 & & 0.91 & 0.15 & 0.79 & 1.00 & 0.99 & 1.00 & 1.00 \\
\hline Mleu & 0.15 & 0.003 & 0.16 & 1.00 & 0.32 & 1.00 & 0.97 & 0.89 & 1.00 & & 1.00 & 1.00 & 0.87 & 1.00 & 0.71 & 0.93 \\
\hline Mjug & 0.002 & $<0.0001$ & 0.002 & 0.92 & 0.008 & 0.59 & 0.24 & 0.12 & 0.62 & 1.00 & & 1.00 & 0.09 & 1.00 & 0.042 & 0.14 \\
\hline Omad & 0.92 & 0.13 & 0.93 & 1.00 & 1.00 & 1.00 & 1.00 & 1.00 & 1.00 & 0.99 & 0.30 & & 0.70 & 0.98 & 0.50 & 0.81 \\
\hline Mgou & 1.00 & 1.00 & 1.00 & 0.07 & 1.00 & 0.25 & 0.61 & 0.81 & 0.37 & 0.026 & $<0.001$ & 0.53 & & 0.98 & 1.00 & 1.00 \\
\hline Mael & 1.00 & 0.65 & 1.00 & 0.87 & 1.00 & 0.99 & 1.00 & 1.00 & 1.00 & 0.62 & 0.033 & 1.00 & 0.97 & & 0.91 & 0.99 \\
\hline Mgle & 1.00 & 0.95 & 1.00 & 0.46 & 1.00 & 0.84 & 0.99 & 1.00 & 0.91 & 0.24 & 0.004 & 0.98 & 1.00 & 1.00 & & 1.00 \\
\hline Mgri & 0.97 & 0.21 & 0.98 & 1.00 & 1.00 & 1.00 & 1.00 & 1.00 & 1.00 & 0.95 & 0.19 & 1.00 & 0.68 & 1.00 & 0.99 & \\
\hline
\end{tabular}

